\title{
PERAN ANGGARAN PARTISIPATIF, GOOD VILLAGE GOVERNANCE DALAM MENINGKATKAN PEMBANGUNAN DESA
}

\author{
Sri Mulyani, Harry Suharman, Srihadi Winarningsih, dan Citra Sukmadilaga \\ Fakultas Ekonomi dan Bisnis, Universitas Padjadjaran \\ Email: sri.mulyani@unpad.ac.id
}

\begin{abstract}
ABSTRAK. Anggaran pada Desa Cibiru Hilir beberapa kali mengalami keterlambatan dalam proses pengajuan anggaran, dan sebagian masyarakat tidak merasa terwakili pada saat pengeluaran pembiayaan dana desa. Pelatihan dalam kegiatan pengabdian pada masyarakat ini bertujuan untuk membuat anggaran yang bersifat partisipatif untuk menampung aspirasi dan kebutuhan masyarakat dalam pengajuan anggaran dana Desa, sehingga Dana desa lebih bisa bermanfaat secara merata untuk pembangunan Desa. Pelatihan menggunakan metode seminar dan diskusi untuk pemecahan masalah sehingga diharapkan bisa menjadi jalan keluar dari permasalahan yang ada di Desa Cibiru Hilir.
\end{abstract}

Kata kunci: Anggaran, Dana Desa, Partisipasi, Akuntabilitas

\section{THE ROLE OF PARTICIPATIVE BUDGET, GOOD VILLAGE GOVERNANCE IN IMPROVING VILLAGE DEVELOPMENT}

\begin{abstract}
Budgets in Cibiru Hilir Village are several fold in the budget submission process, and some people do not feel represented at the time of funding the village funds. Training in community service activities that aims to create a participative budget to accommodate the aspirations and needs of the people in the proposed budget of the Village Fund can be more beneficial for village development. The training uses seminar and discussion methods to explore the problems that can be done in Cibiru Hilir Village.
\end{abstract}

Key words: Budget, Village Fund, Village

\section{PENDAHULUAN}

Pagu anggaran Dana Desa yang dimaksudkan untuk membercepat upaya peningkatan kesejahteraan masyarakata pedesaan mencapai Rp60 triliun (Kemenkeu: 41, 2018). Penyaluran Dana Desa belum terealisasi sepenuhnya, Antara lain disebabkan ada beberapa daerah yang belum menetapkan Perkada tata cara pembagian dan penetapan rincian Dana Desa setiap Desa. Belum adanya kesepakatan antara Kepala Desa dan Badan Permusyawaratan Desa dalam pembahasan rancangan Perdes APBDes. Rendahnya realisasi penyaluran Dana Desa pada daerah tertentu juga menjadikan kurang efektifnya anggaran Dana Desa terserap.

Sinergi pemerintah yang Intensif akan menjadi salah satu solusi untuk mengatasi masalah ini. Penyerapan anggaran akan efektif, jika anggaran yang diajukan sesuai dengan kondisi dan kebutuhan Desa sebagai penerima Dana Desa. Penyusunan anggaran Desa harus sesuai dengan kebutuhan masyarakat. Untuk menyesuikan dengan kebutuhan masyarakat usulan anggaran dilakukan secara partisipatif, dari masyarakat yang diusulkan melalui pengurus Rukun Warga.

Desa Cibiruhilir dalm penyelenggaran penata usahaan kuangan Desa masih terdapat beberapa kekurangan terutama dalam penyusunan anggaran yang tidak tepat waktu. Desa Cibiruhilir mempuyai tujuh puluh sembilan rukun tetangga, tujuh belas rukun warga dan empat dusun (Munawar: 3, 2018). Dengan letak Desa Cibiruhilir yang berbatasan langsung dengan kota Bandung, mengakibatkan pesatnya pertumbuhan penduduk yang disebabkan dengan perpindahan dari desa lain.
Peningkatan jumlah penduduk dan heterogennya tingkat pendidikan dan pekerjaan masyarakat desa menyebabkan kebutuhan masyarakat yang sangat beragam. Kepala Desa harus mampu manampung dan membuat skala prioritas kebutuhan masyarakat. Dengan demikian pada saat melakukan penyusunan anggaran harus mencerminkan kebutuhan masyarakat Desa Cibiruhilir. Penyusunan anggaran harus tepat waktu, sesuai regulasi dan sesuai dengan kebutuhan masyaraktnya. Demikian juga penata usahaan keuangan Desa, harus memenuhi akuntabilitas keuangan Desa.

\section{METODE}

Pelatihan anggaran partisipatif dilaksanakan di Desa Cibiru Hilir kecamatan Cileunyi Kabupaten Bandung. Peserta pelatihan adalah perangkat Desa yang berkaitan degan penyusunan anggaran. Perangkat Desa dalam hal ini terdiri dari: (1) Kepala Desa, (2) Sekretaris Desa, (3) Bendahara Desa, (4) Kepala Seksi, (5) Kepala Urusan, (6) Kepala Dusun, (7) StaffDesa, (8) Badan Permusyawaratan Desa, (9) Lembaga Pemberdayaan Masyarakat Desa, (10) BUMDes, (11) Pembinaan Kesejahteraan Keluarga.

Metode pelatihan menggunakan 3 tahap, (1) melakukan pre test untuk mengetahui tingkat pengetahuan peserta dalam hal penyusunan anggaran dan penata usahaan keuangan Desa. Dalam hal ini juga digunakan untuk lebih memahami dan melengkapi hasil survey mengenai permasalahan yang dialami oleh pihak Desa yang terkait dengan penyusunan anggaran. (2) Penyampaian materi mengenai penyusunan anggaran dan 
akuntabiltas keuangan Desa, penyampaian menggunakan metode seminar dan peserta mendapatkan seminar kits yang berkaitan dengan materi. (3) Melakukaa simulasi yang berkaitan dengan materi dan post test untuk mengetahui keberhasilan kegiatan pelatihan.

Pelatihan dilaksanakan dengan tujuan untuk meningkatkan pengetahuan dan kompetensi dalam penyusunan anggaran secara benar sesuai dengan peraturan pemerintah yang berlaku. Dengan kegiatan pelatihan ini diharapkan penyusunan anggaran sesuai dengan kebutuhan masyarakat melalui anggaran partisipatif. Pelatihan penyusunan anggaran, pertanggungjawaban penerimaan dan pengeluaran anggaran Desa akan lebih meningkatkan kemapuan pihak-pihak terkait dalam penyusunan anggaran dan penataausahaan keuangan Desa. Kegiatan pelatihan penyusunan anggaran ini meliputi : (1) Menyusun anggaran pendapatan, belanja. (2) Rincian anggaran pendapatan Desa. (3) Anggaran pendapatan tidak langsung desa (4) Rekapitulasi rincian anggaran belanja langsung menurut program dam kegiatan Desa. (5) Penerimaan pembiayaan Desa (6) Pengeluaran pembiayaan Desa. Sehingga keuangan Desa akan dikelola berdasarkan asas transparan, akuntabel dan partisipatif (Kemendagri : 3, 2014)

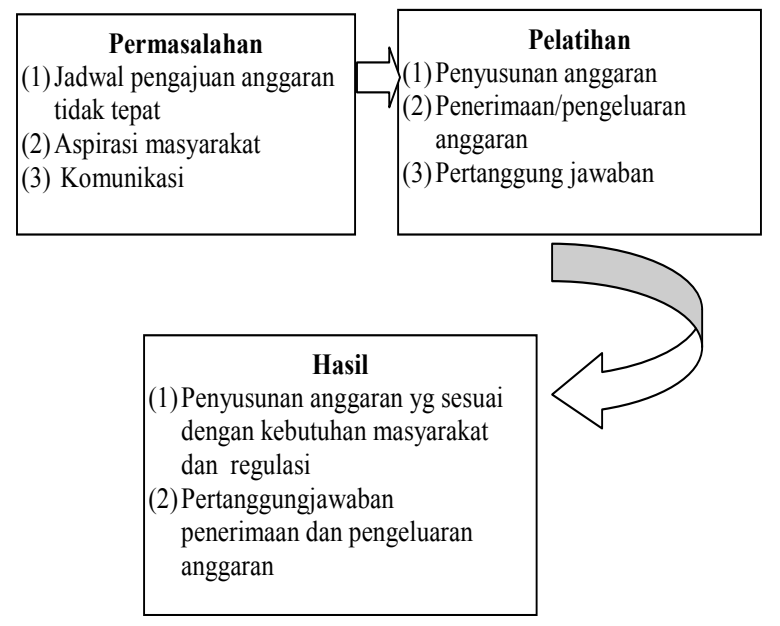

\section{Gambar 1. Kerangka Penyelesaian Masalah}

Berdasarkan gambar tersebut, pelatihan dalam rangka kegiatan Pengabdian Pada Masyarakat melihat permasalahan yang terjadi dilapangan, tim Pengabdian Pada Masyarakat melakukan pelatihan untuk mengatasi permasalah tersebut dengan harapan akan ada hasil. Hasil dari pelatihan ini adalah pengajuan anggaran yang tepat waktu dan sesuai dengan kebutuhan masyarakat dengan adanya partisipasi dari masyarakat desa. Pertanggung jawaban pengeluaran pembiayaan atas penerimaan pembiayaan juga akan lebih baik lagi.

Pelatihan sebagai salah satu unsur untuk menjawab permasalahan, akan digali melalui diskusi, simulasi dan demontrasi pada sesi pelatihan. Peserta akan berperan aktif dan diharapkan akan menyampaikan harapan dan hambatan yang ada selama ini pada saat pengajuan anggaran sampai dengan pertanggungjawaban pengeluaran pembiayaan Desa.

\section{HASIL DAN PEMBAHASAN}

\section{Anggaran Partisipatif}

Anggaran sering dihubungkan dengan masalah perencanaan dan pengendalian (Adisaputro, Gunawan, \& ASri, 1998). Anggaran merupakan Busniness Budget suatu pendekatan yang formal dan sistematis dari pelaksanaan tanggung jawab manajemen didalam perencanaan, koordinasi dan pengawasan. Anggaran bersifat formal, disusun dengan sengaja dan bersungguh-sungguh, sistematis, merupakan suatu tanggung jawab manajer, pelaksanaan fungsi manajer. Anggaran bermanfaat memberikan arah sekaligus target-target yang harus dicapai di waktu yang akan datang (Munandar, 2000). Anggaran partisipatif menggambarkan keterlibatan manajer sebagai pusat pertanggungjawaban dan mengikut sertakan bawahan dan unsur pemangku kepentingan lain. Anggaran partisipatif lebih memberikan memotivasi untuk mencapai tujuan. Anggaran partisipatif merupakan interaksi antara dua inividu atau lebih, atasan dan bawahan untuk menetapkan anggaran dan hasilnya dapat diterima oleh semua pihak. Partisipatif memungkinkan terjadinya komunikasi yang semakin baik, interaksi seta kerjasama dalam tim untuk mencapapi tujuan . Partisipatif merupakan proses penyusunan anggaran dimana para individu terlibat dan memiliki pengaruh dalam penyusunan anggaran (Licata, Michael, Robert, Strawser, \& Robert, 1986). Anggaran partisipatif menujukkan bahwa partisipasi penganggaran memiliki pengaruh positif karena setiap individu berpartisipasi dalam penyusunan anggaran serta memiliki pengaruh terhadap target anggaran. Adanya paprtisipasi dalam anggaran diharapkan mampu membantu jalannya atau proses anggaran agar mencapai hasil yang baik (Ardianti, Suradikha, \& Suputra, 2015). Penyusunan anggaran dengan pendekatan partisipatif adalah dengan menggabungkan kedua pendekatan dari atas ke bawah dengan dari bawah keatas. Penyusunan anggaran dengan pendekatan ini dimulai dari bawahan menyiapkan draft pertama untuk anggaran di wilayah tanggung jawabnya, berdasarkan pedoman atau regulasi yang berlaku. Selanjutnya atasan akan memeriksa dan mengkritisi anggaran yang diusulakan melalui proses musyawah. Prose penyusunan anggaran dengan metode partisipatif diharapkan lebih efektif. Penyusunan anggaran pada organisasi pemerintahan pada dasarnya mempunyai kesamaan bila dibandingkan dengan oganisasi yang motifnya mencari laba. Beberapa kesamaan tersebut adalah (1) Organisasi pemerintah merupakan bagian dari sistem ekonomi yang sama dan menggunakan sumber daya yang sama juga untuk memenuhi tujuannya. (2) Organisasi pemerintah juga harus menggunakan sumber daya yang terbatas untuk meciptakan barang dan jasa sehingga memerlukan anlisis biaya dan pengendalian biaya untuk memastikan bahwa sumber daya yang langka tersebut telah digunakan secara efesuen dan efektif (Soeleman, 2012). 
Desa memiliki potensi sumebr daya alam yang cukup besar ternyata belum mampu membuat tingkat perekonomian desa yang merata, hal ini ditunjukkan dengan adanya kesenjangan ekonomi yang cukup besar (Rochdiani, Kusumo, Wibowo, Qanti, \& Sadeli, 2018). Dana desa dapat menjadi solusi dalam mengatasi masalah-masalah pedesaan yang belum tersentuh, dengan demikian penyusunan anggaran harus berpihak pada masyarakat, gender, perluasan lapangan kerja, dan kelestarian lingkungan untuk pengembangan sarana dan prasarana Desa, potensi ekonomi lokal dan pemanfaatan sumber daya yang berkelanjutan (Kemendes : 3, 2015). Penyusunan anggaran dan penatausahaan dana Desa berhubungan dengan implikasi kesadaran pada lingkungan dan tanggung jawab sosial yang akan secara positif mempengaruhi organisasi di masa depan (Suharman, 2012). Evaluasi Pengajuan pelaksanaan RKP Desa tahun sebelumnya menjadi landasan untuk pengajuan tahun berjalan yang ditetapkan dengan Perdes dan Sekdes menyusun Raperdes APBDesa dan pada paling lambat bulan Oktober disepkati antara Desa dan BPD, baru diproses ketingkat selanjutnya (Presiden : 12, 2014).

Pelatihan penyusunan anggaran partisipatif dilakukan secara tepat dengan penyampaian materi yang relevan, Materi menggunakan ketentuan yang terbaru dari regulator yaitu (1) Permendagri nomor 113 tahun 2014 tentang pengelolaan keuangan Desa. (2) Permendagri nomor 114 tahun 2014 tentang pedoman pembangunan desa. (3) Kemendes nomor 5 tahun tahun 2015 tentang penetapan prioritas penggunaan dana Desa. (4) Perpu Nomot 6 tahun 2014 tentang Desa. Pelatihan disampaikan dengan jelas dan runut dengan melibatkan peserta latihan dalam simulasi penyusunan anggaran maupun penataushaan keuangan Desa. Pelatihan dilakukan di kantor desa Cibiruhilir dan diikuti perangkat Desa yang terkait dengan proses pengajuan anggaaran dana Desa dan penatasusahaan dana Desa. Peserta pelatihan terdiri pengurus di lingkungan Rukun Warga, terutama pengurus yang baru terpilih dalam pergantian struktur organisasi Desa Cibiruhilir, staf kantor Desa, BKD, termasuk pengurus BUMDes sebagai salah satu sumber pendaptan Desa Cibiruhilir. BUMDES belum lama didirikan dan lahir sebagai suatu pendekatan baru dalam usaha peningkatan ekonomi Desa berdasarkan kebutuhan dan potensi Desa. Pengelolaan BUMDes sepenuhnya dilakukan oleh masyarakat Desa Cibiruhilir, yaitu dari Desa, oleh Desa dan untuk Desa. Pelatihan terutama untuk pengurus baru sangat perlu, sehinnga pengurus memahami cara kerja BUMDES. BUMDes akan memfasilitasi, menampung kegiatan-kegiatan ekonomi masyarakat dalam sebuah bentuk kelembagaan atau badan usaha yang akan dikelola secaran profesional, namun tetap bersandar pada potensi asli Desa. Hal ini dapat menjadikan usaha masyarakat sebagai pemberdayaan ekonomi sekaligus menjadi pendapatan Desa (Zulkarnaen, 2016).

Pada saat pelatihan peserta sangat antusias terutama pada sebagian pengurus baru dilingkungan Desa. Petaihan ini sangat tepat karena menyamakan pemahaman antara pengurus agar bisa melakukan penyusunan anggaran sesuai ktentuan yang beraku. Alat yang digunakan dalam pelatihan ini berupa kertas kerja yang digunakan masing-masing peserta untuk mempraktekan bagaimana anggaran diajukan dan diproses dari awal sampai akhir. Kertas kerja dan diskusi dilaksanakan setelah pemberian materi dengan metode seminar, untuk menggali aspirasi masyarakt yang selama ini belum muncul dalam proses pengajuan anggaran. Kendala yang sering terjadi adalah ketelambatan dalam penyampaian usulan anggara, dalam pelatihan diarahkan mekanisma penggunaan time line dari metode penyusunan anggaran partisipatif. Desa Cibiruhilir dari waktu ke waktu semakin berkembang, karena lokasi Desa sebagai penyangga kota Bandung. Urban dari luar kota Bandung banyak yang menilih domisili di Desa Cibiruhilir. Adanya pendatang dari berbagai daerah yang menetap, maka tingkat heterogen masyarakt desa semakin meningkat. Heterogen dari sisi budaya, tingkat sosial, ekonomi dan kebutuhan saran serta prasarana yang dibutuhkan oleh masyarakat Desa. Dengan beragamnya kebutuhan masyarakat, pengajuan anggaran yang diusulkan oleh masyarakat Desa menjadi sangat variatif dan ingin semua di akomodir. Pengajuan dari masingmasing kepala Dusun ingin di akomodir terlebih dahulu, meskipun ada beberapa keterlambatan dalam pengajuan anggaran dari lingkungan Dusun yang masuk ke kantor Desa. Sedangkan Desa menyetujui dan mengajukan usulan melalui kecamatan memerlukan beberapa prosedur. Masyarakat kadang kurang memahami dan beranggapan jika sudah mengajukan otomatis di setujui dan Dana Desa dapat segera dicairkan untuk digunakan.

Pelatihan ini termasuk melakukan sosialisasi penyusunan anggaran partisipatif untuk membangun kesadaran masyarakat mengenai prosedur atau tata caranya agar tepat waktu, efektif dan sesuai dengan prioritas kepentingan Desa atas dasar musyawarah. Penyusunan anggaran partisipatif pada saat pelatihan diarahkan dengan terlebih dahulu dimulai dengan musyawarah Dusun. Musyawarah dusun di desa Cibiruhilir merupakan titik awal pelaksanaan anggaran partsisipatif. Musayawarah dilakukan untuk mendapatkan masukan rencana pembangunan desa cibiru hilir secara parisipatif. Masyarakat bersama-sama mengidentifikasi potensi dan permasalahan dilingkungan RW atau Dusun mencakup bidang sosial budaya, ekonomi produktif warga dan sarana prasaran fisik lingkungan, termasuk alternatif dan solusi masalahnya. Dengan musyawaran di lingkungan Dusun, Ketua Rukun Warga memimpin musyawarah penyusunan anggaran paling lambat minggu ke tiga setiap bulan Januari, maka semua aspirasi masyarakat bisa diajukan tepat waktu ke tingakt Desa Keputusan atau hasil musyawarah dilingkungan Dusun akan diajukan dalam musayawarah anggaran tingkat Desa. Musyawarah Desa dimulai dengan diterima draft anggaran dari masing-masing Dusun dan akan disusun berdasarkan skala prioritas oleh tim penyusun 
RKP. Kesepakatan prioritas anggaran yang akan disusun dalam proposal dimusyawarahkan oleh Pemerintah Desa, BPD dan perwakilan warga Dusun agar dapat disetujui bersamai. Dokumen di proses lebih lanjut untuk pembuatan proposal APBDesa dan akan disampaikan ke pihak Kecamatan sebagai pengajuan proposal APBDesa. Pelatihan sangat membantu memecahkan masalah time line pengajuan rencana anggaran dalan penyusunan anggaran di Desa Cibiruhilir, pelatihan dikatakan berhasil dilihat dari hasil pre test dan hasil post test setelah seminar dan simulasi penyusunan anggaran.

\section{Good Village Governance}

Akuntabilitas sistem pengelolaanAlokasi Dana Desa (ADD) dimaksudkan sebagai upaya untuk mewujudkan tata kelola pemerintahan Desa yang baik (Good Village Governance). Prinsip Good Village Governance adalah partisipasi, transparsni dan pertnggungjawaban dalam ppelaksanaan pemerintahan maupun pembangunan. Tingkat akuntabilitas dalam implementasi pengelolaan Alokasi Dana Desa dimulai dari tahap perencanaan, pelak-sanaan dan pertnggungjawaban sebagaimana diatur dalam pedoman pelaksanaan Alokasi Dana Desa (Arifiyanto \& Kurrohman, 2014). Penatausahaan keuangan Desa dimaksudkan sebagai upaya untuk mewujudkan tata kelola pemerintahan yang baik, dengan adanya partisipasi, transparani dan pertanggung jawaban dalam pelaksanaan pemerintahan maupun pengelolaan dana Desa, dimulai dari tahap perencanaan, pelaksanaan dan pertanggungjawaban (Haryanto, Sahmuddin, \& Arifuddin, 2007). Praktek Good Governance di tingkat desa masih sulit dilakukan, hal ini karena anggapan bahwa sumber daya (khususnya manusia dan organisasi) yang ada di sebagian besar Desa di Indonesia masih mengalami keterbatasan. Peraturan sering berubah-rubah sehingga menuntut perangkat Desa harus aktif mengikuti peraturan yang terbaru. Dari segi aspek lain perangkat Desa harus mampu menyusun laporan keuangan untuk dipertanggungjawabkan kepada pemberi sumber dana desa yaitu Pemerintah Pusat, Pemerintah Provinsi, Pemerintah Kabupaten (Sofyani, Suryanto, Wibowo, \& Widiastuti, 2018). Tata kelola administrasi desa diharapkan mampu membawa perubahan yang fundamental terhadap pembangunan bangsa berbasis masyarakat pedesaan. Pemerintah Kabupaten dan Kecamatan harus berperan untukmelakukan fungsipembinaan dan fungsipengawasan terhadap penyelenggaraan tata kelola pemerintahan Desa, Peran seta ini harus nyata dan berkelanjutan agar supaya pengelenggaraaan pemerintahan desa sebagai salah satu unsur terpenting dalam merealisasi kebijakan Desa yang berorientasi kepada kesejahteraan masyarakat. Good Village Governance menjadi salah satu unsuryang berperan dalam meningkatkan pembangunan Desa. Penatausahaan kuangan Desa harus ditekankan dari sisi pelaksanaan, penatausahaan, aspek perpajakan dan pengelolaan alokasi dana desa, pengelolaan bantuan keuangan dan pengelolaan dana lain. Penyelenggaraan manajemen pembangunan yang solid dan bertanggungjawab yang sejalan dengan pinsip demokrasi dan pasar uang efisien sehingga good governance berfungsi sebagai penghindaran pencegahan korupsi baik secara politik maupun secara administrasi. Untuk mencapai Good Village Governance dalam tata kelola pemerintahan Desa maka prinsip-prinsip good governance hendaknya ditegakkan prinsip good governance dalam pemerintahan, prinsip-prinisp ini meliputi partisipasi masyarakat, tegaknya supermasi hukum, transparani, peduli, stakeholder bereorientasi pada konsensus, kesetaraan bagi semua warga, efektifitas dan efisiensi, akuntabilitas (Putra, 2017)

Bendahara dalam hal ini sebagai penerima mandat dari Kepala Desa, mempunyai tugas menerima, menyimpan, menyetorkan, menatausahakan dan mempertanggung-jawabkan penerimaan dan pendapatan Desa dan pengeluaran pendapatan Desa dalam rangka pelaksanaan APBDesa. Bendahara mendapatkan bukti transaksi atas pendapatan dan pengeluaran. Bendahara juga bertanggung jawab atas pelaksanaan tugasnya kepada kepala Desa (Permendagri, 2014b). Laporan keuangan dapat menggambarkan kualitas manajemen keuangan pemerintah dengan melihat pengungkapan laporan keuangan dapat diketahui informasi penting mengenai pengelolaan keuangan dan akuntabilitas serta tata kelola pemerintahan (Sukmadilaga, Pratama, \& Mulyani, 2015) . Unsur pemerintah dan masyarakat Desa harus saling bekerjasama untuk menjadikan pemerintah Desa yang baik melalui akuntabilitas, transparansi dan aturan hukum sebagai pilar good vilage governance untuk meningkatkan pembangunan dam kesejahteraan masyarakat Desa.

Alur penatausahaan kuangan Desa yang disampaikan dalam pelatihan sebagai mana gambar berikut (Permendagri, 2014a).

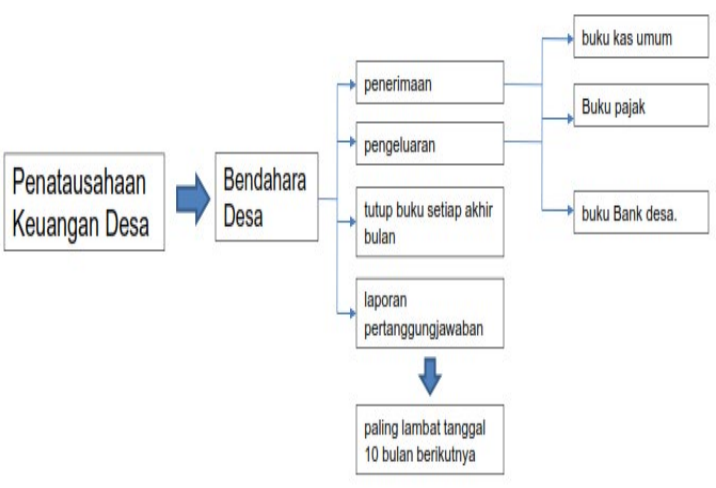

Gambar 2. Penatausahaan keuangan Desa

Laporan Keuangan merupakan salah satu bentuk pertanggungjawaban yang dilakukan Pemerintah Desa khususnya dalam pengelolaan keuangan Desa. Desa Cibiruhilir dalam proses menyusun laporan keuangan sudah menggunakan sistem, maka diperlukan entry data yang akan dijadikan parameter sebagai bahan baku untuk pengolahan data (Mulyani, 2016). Pelaporan keuangan bisa melalui dua bentuk yaitu secara subtantif dan normatif. 
Subtantifnya pemerintah desa melakukan pelaporan setiap 3-4 bulan sekali yakni melalui musyawarah yang dilakukan oleh pemerintah desa dengan mitra kerjanya. Dengan adanya pelaporan tersebut akan mempermudah dalam proses evaluasi atas pelakasanaan program atau kegiatan. Secara normatifnya pemerintah desa berkewajiban melaporkan setiap kegiatan atau program yang dibiayai oleh alokasi dana Desa dengan membuat sebuah laporan SPJ kepada Kabupaten dengan persetujuan Kecamatan. Dalam laporan tersebut berisi daftar perencanaan program atau kegiatan yang dibiayai oleh alokasi dana Desa hingga bukti-bukti dokumentasi dan apapun yang berhubungan dengan program yang dibiayai (Fajri, Setyowati, \& Siswidiyanto, 2012).

Dalam pelatihan ditekankan bahwa akuntabilitas laporan keuangan Desa menjadi salah satu faktor yang akan menentukan pemerintahan Desa yang baik. Pelatihan pengelolaan penerimaan anggaran desa dan pengeluaran anggaran desa dibuat dengan lebih menarik, selain menyampikan materi dengan metode seminar, juga diadakan simulasi dan diskusi kelompok untuk menggali permasalahan yang selama ini timbul dalam pelaksanaan penatausahaan keuangan Desa.

Pergantian pengurus atau staf Desa di bagian keuangan pada Desa Cibiruhilir kadang menjadi kendala dalam tata kelola keuangan Desa. Berbedanya pengalaman dan pengetahuan tentang tata kelola pemerintahan dapat di minimalisir dengan pelatihan kompetensi sumber daya mannusia, salah satunya dengan pelatihan dari tim kami. Pelatihan pengelolaan penerimaan anggaran desa sangat bermanfaat untuk mengenalkan dan membentuk Good Village Governance di Desa Ciibiruhilir. Pelatihan penatausahaan keuangan Desa meliputi penatausahaan, aspek perpajakan dan pengelolaan dana desa maupun dana bantuan keuangan yang baku dan atau sesuai regulasi. Dengan pelatihan diharapkan staf Desa yang berhubungan dengan penerimaan anggaran dan penggunaan anggaran di Desa Cibiru lebih kompeten. Diharapkan lebih memahami alur penatausahaan keuangan Desa sebagaimna diatur dalam Pemendagri tahun 2014 yang disosialisasikan. Pemahaman yang jelas dan kemampuan mengikuti prosedur penatausahaan keuangan Desa membantu tenaga pengelola bisa bekerja dengan lebih efektif, efesien dan transparansi sesuai dengan prinsip Good Village Governance. Dari perbandingan hasil evaluasi sebelum dan setelah pelatihan, dapat dilihat bahwa dengan pelatihan yang tepat tenaga atau staf pada bagian pengelolaan keuangan di Desa Cibiruhilir lebih memahami dan mampu melakukan tata kelola keuanngan Desa dengan baik. Penatausahaan keuangan Desa yang baik dari anggaran sampai dengan laporan pertanggung jawaban penerimaan anggaran, menjadi salah satu unsur tercapainya Good Village Governance. Khususnya Good Village Governance di desa Cibiruhilir. Dengan demikian pembangunan Desa akan berjalan dengan baik dan kesejahteraan masyarakat Cibiruhilir akan meningkat.

\section{SIMPULAN}

Pelatihan penyusunan anggaran dan penatausahaan keuangan Desa, dilihat dari perbandingan hasil pre test dan post test ada peningkatan kompetensi peserta dan peserta lebih memahani tata cara penyusunan anggaran partisipatif, dan akuntabilitas kuangan Desa yang akan mendukung tercapainya good vilage governance dengan diterapkannya regulasi yang berlaku dan partisipatif warga agar sesuai dengan kebutuhan warga masyarakt dan pertanggungjawaban yang transparan. Terpenuhinya hal tersebut akan menjadi salah satu unsur dalam meningkatkan pembangunan Desa.

\section{DAFTAR PUSTAKA}

Adisaputro, Gunawan, \& ASri, M. (1998). Anggaran Perusahaan (3rd ed.). Yogyakarta: BPFE.

Ardianti, P. N. H., Suradikha, I. M. S., \& Suputra, I. D. G. D. (2015). Pengaruh Penganggaran Partisipatif pada Budgetary Slack dengan Asimettri Informasi, Self Esteem, Locus of Control dan Kapasitas Individu Sebagai Variabel Moderasi. E-Jurnal Ekonomi Dan Bsinis Universitas Udayana, 4(05), 296-311.

Arifiyanto, D. F., \& Kurrohman, T. (2014). Akuntabilitas Pengelolaan Alokasi Dana Desa Di Kabupaten Jember. Jurnal Riset Akuntansi Dan Keuangan, 2(3), 473-485.

Fajri, R., Setyowati, E., \& Siswidiyanto. (2012). Akuntabilitas Pemerintah Desa Pada Pengelolaaan Alokasi Dana Desa. Jurnal Administrasi Publik (JAP), 3(7), 1099-1104.

Haryanto, Sahmuddin, \& Arifuddin. (2007). Akuntansi Sektor Publik Edisi Pertama. Semarang: Universitas Diponegoro.

KMK. (2018, May). APBN Kita. Kememterian Keuangan Republik Indonesia, 1-29.

Licata, Michael, P., Robert, H., Strawser, \& Robert, B. W. (1986). A Note on Participation in Budgeting and Locus of Control. The Accounting Review, LXI(1).

Mulyani, S. (2016). Metode Analisis dan Perancangan Sistem (1st ed.). Bandung: Abdi Sistematika.

Munandar, M. (2000). Budgeting Perencanaan Kerja, Pengkoordinasian Kerja, Pengawasan Kerja (1st ed.). Yogyakarta: BPFE.

Munawar, I. (2018). Profil Desa Cibiruhilir Kabupaten Bandung. Bandung.

Permendagri. Pedoman Pembangunan Desa, Pub. L. No. 114, 1 (2014). Indonesia: Menteri Dalam Negeri Republik Indonesia. 
Permendagri. Pengelolaan Keuangan Desa, Pub. L. No. 113, 1 (2014). Indonesia: Menteri Dalam Negeri Republik Indonesia.

Permendagri. Penetapan Prioritas Penggunaan Dana Desa Tahun 2015, Pub. L. No. 05, 1 (2015). Indonesia: Menteri Desa, Pembangunan Daerah Tertinggal, dan Transmigrasi Republik Indonesia.

PERPU. Peraturan Pelaksanaan Undang-undang Nomor 6 Tahun 2014 Tentang Desa, Pub. L. No. 43, 1 (2014). Indonesia: Presiden Republik Indonesia.

Putra, H. S. (2017). Tata Kelola Pemerintahan Desa Dalam Mewujudkan Good Governance di Desa Kalibelo Kabupaten Kediri. Jurnal Politik Muda, 6,(2), 110-119.

Rochdiani, D., Kusumo, R. A. B., Wibowo, S. N., Qanti, S. R., \& Sadeli, A. H. (2018). Manajemen Usaha Home Industry Desa Sindangsari Kecamatan Sukasari Kabupate Sumedang. Dharmakarya: Jurnal Aplikasi Ipteks Untuk Masyarakat, 7,(1), 51-55.

Soeleman, R. (2012). Pengaruh Penganggaran Partisipatif Terhadap Kinerja Manajerial dengan Budaya
Organisasi dan Gaya Kepemimpinan Sebagai Variabel Moderating. Siasat Bisnins, 16(1), 87105.

Sofyani, H., Suryanto, R., Wibowo, S. A., \& Widiastuti, H. (2018). Praktik Pengelolaan dan Tata Kelola Pemerintahan Desa Dlingo di Kabupaten Bantul : Pembelajaran dari Desa Percontohan. Jurnal Akuntansi Terapan Indonesia, 1,(1), 1-16.

Suharman, H. (2012). The Influence of Corporate Social Performance, Budget Emphasis, Participative Budget on Job Related Tension. World Journal of Social Sciences, 2,(7), 48-63.

Sukmadilaga, C., Pratama, A., \& Mulyani, S. (2015). Good Governance Implementation in Public Sector: Exploratory Analysis of Government Financial Statements Disclosures Across ASEAN Countries. Procedia - Social and Behavioral Sciences, 211(September), 513-518.

Zulkarnaen, R. M. (2016). Pengembangan Potensi Ekonomi Desa Melalui Badan Usaha Milik Desa (BUMDES) Pondok Salam Kabupaten Purwakarta. Dharmakarya: Jurnal Aplikasi Ipteks Untuk Masyarakat, 5,(1), 1-4. 